Пукас К. В., лікар-кардіолог відділення хірургічного лікування набутих вад серця

ДУ «Національний інститут серцево-судинної хірургії імені М. М. Амосова НАМН України», м. Київ, Україна

\title{
Тромбоемболічні ускладнення у віддалений термін при протезуванні мітрального клапана
}

\begin{abstract}
Резюме. Протезування клапанів серця є найефективнішим методом корекції вад серця, який дозволяє усунути патологічні зміни, поліпшити внутрішньосерцеву гемодинаміку та якість життя пацієнтів. Однак наявність штучного протеза, фібриляція передсердь та особливості морфометрії лівого передсердя, скоротливості лівого шлуночка призводять до тромбоемболічних ускладнень (ТУ) [1, 4, 8]. Вивчення цих ускладнень у віддалений термін після протезування мітрального клапана було метою цього дослідження.

До групи аналізу включено 634 пацієнти з ізольованою мітральною вадою, які перебували на лікуванні в Національному інституті серцево-судинної хірургії імені М. М. Амосова з 1 січня 2005 по 1 січня 2007 року. Середня тривалість спостереження становила 9,3 \pm 0,9 року. Основні показники, які вивчали впродовж 10 років: виживаність - 69,4 \%, стабільність хороших та задовільних результатів - 57,3 \%, запобігання ТУ 79,7 \%, запобігання повторним операціям - 95,4 \%. На підставі проведеного аналізу були визначені чинники ризику ТУ у віддаленому періоді: тип імплантованого протеза, адекватність антикоагулянтної терапії, виникнення протезозалежних ускладнень (протезний ендокардит, панус або тромбоз мітрального протеза) $[3,8,9]$. Протезування мітрального клапана рекомендоване пацієнтам II-III функціонального класу та за наявності синусового ритму. Після операції пацієнти (особливо групи ризику) повинні перебувати під постійним диспансерним наглядом.
\end{abstract}

Ключові слова: мітральна вада, протезування мітрального клапана, тромбоемболія, віддалений період, хірургічне відновлення ритму серия.

Незважаючи на поліпшення безпосередніх результатів операції, віддалена ефективність хірургічної корекції вад серця часто не задовольняє лікаря. Зазвичай оцінювання віддалених результатів операції проводять за такими показниками: функціональний клас за класифікацією NYHA, виживаність, стабільність клінічної симптоматики, відсутність тромбоемболії, відсутність геморагічних ускладнень, частота розвитку дисфункції протеза, а також функціональний стан протеза і якість життя хворих $[2,8,10]$. Для корекції вад серця на сьогодні застосовують як механічні, так і біологічні протези, кожний з яких має недоліки та переваги [6, $9,10]$. Специфічними ускладненнями у хворих з механічними клапанами серця є тромбоемболії, які трапляються з частотою $0,05-3,5 \%$.

Мета роботи - вивчення причин і частоти виникнення тромбоемболічних ускладнень у віддалений термін після протезування мітрального клапана.

Матеріали та методи. До групи дослідження включено 634 послідовно прооперованих пацієнтів з ізольованою мітральною вадою, які перебували на лікуванні в Національному інституті серцево-судинної хірургії імені М. М. Амосова НАМН України з 1 січня 2005 по 1 січня 2007 року. Це становило 96,7 \% від кількості виписаних пацієнтів на госпітальному етапі $(\mathrm{n}=656) .3$ дослідження виключено пацієнтів із супутньою помірною аортальною вадою. Чоловіків було 299 (47,1 \%), жінок - 335 (52,9 \%). Середній вік пацієнтів $-53,1 \pm 8,5$ року. $55(34,1 \%)$ пацієнтів належали до II функціонального класу (ФК) за класифікацією NYHA, 199 (31,7 \%) - до III ФК та 380 (60 \%) - до IV ФК. Найпоширенішою етіологічною причиною вади був ревматизм у поєднанні з ліпоїдозом та міксоматозом (67,5\%). Середня тривалість існування вади сягала $17,3 \pm 4,9$ року. Середня тривалість фібриляції передсердь $-3,1 \pm 0,9$ року.

Усім пацієнтам виконано протезування мітрального клапана (ПМК). Під час ПМК використовували такі типи двостулкових клапанних протезів - Saint Jude, On-X, Carbomedics, Edwards-Mira [3, 8, 10].

Корекцію трикуспідальної вади (анулопластика за Амосовим - де Вегою) виконували у 125 (19,7 \%) пацієнтів. У 97 (15,3\%) пацієнтів виконано аортокоронарне шунтування. Попередня операція на серці (закрита мітральна комісуротомія) - у 119 (18,7 \%) пацієнтів.

Відновлення синусового ритму під час операції відбувалось шляхом проведення радіочастотної абляції лівого передсердя (ЛП) за варіантом операції лівого 
«Лабіринту-3» у 29 (4,6 \%) пацієнтів. При дилатації ЛП додатково виконували його редукцію у $47(7,4 \%)$ пацієнтів шляхом параанулярної плікації задньої стінки ЛП з метою зменшення розміру ЛП $<5,0 \mathrm{~cm}$. Вихідний розмір ЛП становив $63,7 \pm 1,8$ мм.

Результати та обговорення. Середня тривалість спостереження сягала 9,3 $\pm 0,9$ року. Основні показники, які вивчали на цьому етапі: виживаність $-69,4 \%$, стабільність хороших і задовільних результатів - 57,3 \%, запобігання ТУ - 79,7 \%, запобігання повторним операціям - 95,4\%.

Структура незадовільних результатів при ПМК ( $\mathrm{n}=$ 74) була зумовлена: прогресуючою серцевою недостатністю - 31,1\%, тромбоемболічними ускладненнями $37,8 \%$, прогресуючою ішемічною хворобою серця (IXC), гіпертонічною хворобою - $1 \%$.

Тромбоемболічні ускладнення (ТУ) траплялись у 83 $(13,1 \%)(\mathrm{n}=83 / 634)$ пацієнтів. Вони були розподілені на 3 категорії: 1) легкі ( $\mathrm{n}=17)$, при яких перенесені тромбоемболічні явища мали транзиторний характер, не залишаючи дисфункції органів-мішеней; 2) тяжкі $(\mathrm{n}=22)$, при яких відзначались залишкові явища, які впливали на подальшу функцію органа-мішені; 3) летальні $(\mathrm{n}=44)$. За наявності правильного ритму серця тромбоемболічні ускладнення відзначали у $5(8,2 \%)$ (n = 5/61), за наявності фібриляції передсердь - у 78 $(13,6 \%)(\mathrm{n}=78 / 573)$ пацієнтів $(\mathrm{p}<0,05)$. Структура ускладнень залежно від ФК представлена в таблиці 1.

Згідно з даними таблиці 1, найбільша кількість тромбоемболічних ускладнень у структурі припадає на летальні випадки - 53,0 \% (53,7 \% (n= 44/83) - серед усієї кількості тромбоемболічних ускладнень: тяжкі $26,5 \%$ та легкі - 20,5\% (p < 0,01)). Однак більша питома вага летальних ТУ припадає на пацієнтів IV ФК порівняно з II-III ФК: 63,8 \% проти 28,0 \% (p < 0,01). Це співвідношення свідчить про передопераційні чин-

\section{Таблиця 1}

Структура ТУ у віддалений термін залежно від ФК за NYHA

\begin{tabular}{|c|c|c|c|c|c|c|}
\hline \multirow[b]{2}{*}{ Причини } & \multicolumn{2}{|c|}{$\begin{array}{c}\text { II-III ФК } 3 a \\
\text { NYHA } \\
(n=254)\end{array}$} & \multicolumn{2}{|c|}{$\begin{array}{c}\text { IV ФК за } \\
\text { NYHA } \\
(n=380)\end{array}$} & \multicolumn{2}{|c|}{$\begin{array}{c}\text { Усього } \\
(n=634)\end{array}$} \\
\hline & $n$ & $\%$ & $\mathrm{n}$ & $\%$ & $\mathbf{n}$ & $\%$ \\
\hline $\begin{array}{l}\text { Тромбоемболічні } \\
\text { ускладнення } \\
\text { (легкі) }\end{array}$ & 11 & 44,0 & 6 & 10,4 & 17 & 20,5 \\
\hline $\begin{array}{l}\text { Тромбоемболічні } \\
\text { ускладнення } \\
\text { (тяжкі) }\end{array}$ & 7 & 28,0 & 15 & 25,8 & 22 & 26,5 \\
\hline $\begin{array}{l}\text { Тромбоемболічні } \\
\text { ускладнення } \\
\text { (летальні) }\end{array}$ & 7 & 28,0 & 37 & 63,8 & 44 & 53,0 \\
\hline Усього & 25 & 100,0 & 58 & 100,0 & 83 & 100,0 \\
\hline
\end{tabular}

ники IV ФК, які призвели до найбільшого показника. Відсоток летальних ТУ серед пацієнтів II-III ФК становив 2,75 ( $\mathrm{n}=7 / 254)$, що є менше, ніж для пацієнтів IV ФК 9,7\% (n=37/380) (p < 0,01). Тяжкі ТУ в структурі тромбоемболії (ТЕ) досягли 26,5 \% (n = 22/83) ceред усієї кількості ТУ. Однак менша питома вага тяжких ТУ припадала на пацієнтів IV ФК за NYHA, ніж на II-III ФК: 28,0 \%, проти 25,8 \% (p > 0,05). Відсоток тяжких ТУ серед пацієнтів II-III ФК за NYHА становив $2,75(\mathrm{n}=7 / 254)$, що є менше, ніж для пацієнтів IV ФК - 3,9\% (n = 15/380) $(\mathrm{p}<0,05)$. Легкі тромбоемболічні ускладнення в структурі ТУ досягли $20,5 \%$, що становило $20,5 \%(\mathrm{n}=17 / 83)$ серед загальної кількості ТУ. Однак менша питома вага легких ТУ припадала на пацієнтів IV ФК, ніж на пацієнтів II-III ФК: $44,0 \%$ проти $10,48 \%$ ( $<0,05)$. Відповідно, відсоток легких ТУ серед пацієнтів II-III ФК становив 4,3 (n = 11/254), що є менше, ніж для пацієнтів IV ФК - 1,6\% $(\mathrm{n}=6 / 380)(\mathrm{p}<0,05)$.

Отже, летальні та тяжкі ТУ відзначали у $89,6 \%$ у структурі серед пацієнтів IV ФК, водночас як серед пацієнтів II-III ФК відповідно 56 \% (p < 0,05). Таке співвідношення свідчить про вплив на тромбоемболічні епізоди таких чинників, як довготривала фібриляція передсердь, довготривала ревматична вада, знижена скоротливість лівого шлуночка (ЛШ), дилатація ЛП, які більшою мірою наявні в групі пацієнтів IV ФК.

Наявність аритмії серця впливає на прояв ТУ і, відповідно, на ступінь цього ускладнення (таблиця 2). Відсутність правильного ритму суттєво знижує якість прояву тромбоемболічних ускладнень, за яких відзначається питома вага летальних і тяжких ускладнень порівняно з групою хворих із синусовим ритмом, де переважають тільки легкі ТУ $(\mathrm{p}<0,01)[5,7,10]$. За частотою ТУ група пацієнтів із синусовим ритмом суттєво відрізняється від групи з фібриляцією передсердь: $4,1 \%(\mathrm{n}=5 / 121)$ та $15,2 \%(\mathrm{n}=78 / 513)(\mathrm{p}<0,05)$.

Дилатація ЛП є найхарактернішою для IV ФK, особливо за наявності фібриляції передсердь, та їі чинник впливає на ступінь ТУ (таблиця 3). Відсутність правильного ритму суттєво знижує якість прояву тромбоемболічних ускладнень, за яких відзначається питома вага летальних і тяжких ускладнень при

\section{Таблиця 2}

Структура ТУ залежно від ритму серия

\begin{tabular}{|c|c|c|c|c|}
\hline \multirow[b]{2}{*}{ Ритм } & \multicolumn{4}{|c|}{$\begin{array}{c}\text { Ступінь прояву тромбоемболічних } \\
\text { ускладнень }\end{array}$} \\
\hline & Тяжкі & Легкі & Летальні & Усього \\
\hline Синусовий & $7, \frac{1}{7} \%$ & $84,6 \%$ & $7, \frac{1}{7} \%$ & $\stackrel{5}{100,0} \%$ \\
\hline $\begin{array}{l}\text { Фібриляція } \\
\text { передсердь }\end{array}$ & $30,0 \%$ & $8,6 \%$ & $\frac{43}{61,4} \%$ & $10 \frac{78}{0,0} \%$ \\
\hline
\end{tabular}




\section{Таблиця 3}

Структура ТУ при ПМК залежно від розміру ЛП в групі з фібриляцією передсердь $(n=78)$

\begin{tabular}{|c|c|c|c|c|}
\hline \multirow{3}{*}{$\begin{array}{l}\text { Розмір ЛП } \\
\text { до операції } \\
\text { (см) }\end{array}$} & \multicolumn{4}{|c|}{ Ступінь прояву тромбоемболічних ускладнень } \\
\hline & $\begin{array}{c}\text { Тяжкі } \\
\text { (n = 21) }\end{array}$ & $\begin{array}{c}\text { Легкі } \\
(n=14)\end{array}$ & $\begin{array}{c}\text { Летальні } \\
\text { (n = 43) }\end{array}$ & $\begin{array}{c}\text { Усього } \\
(n=78)\end{array}$ \\
\hline & $\mathbf{n}$ & $\%$ & $\mathbf{n}$ & $\%$ \\
\hline$<4,0$ & $0, \underline{0} \%$ & $\frac{1}{100,0} \%$ & $0, \underline{0} \%$ & $\frac{1}{100,0} \%$ \\
\hline $4,1-4,5$ & $0, \underline{0} \%$ & $\underline{2}$ & $0, \underline{0} \%$ & $\underline{2}$ \\
\hline $4,6-5,0$ & $10, \frac{1}{0} \%$ & $60,0 \frac{6}{0} \%$ & $30, \frac{3}{0} \%$ & $10 \stackrel{10}{10,0} \%$ \\
\hline $5,1-5,5$ & $36, \underline{4} \%$ & $18 \frac{2}{2} \%$ & $45 \stackrel{5}{4} \%$ & $10 \frac{11}{0,0} \%$ \\
\hline $5,6-6,0$ & $33 \frac{5}{3} \%$ & $13, \frac{2}{3} \%$ & $53 \underline{8}, 4 \%$ & $100,0 \%$ \\
\hline$>6,0$ & $28 \stackrel{11}{28,2} \%$ & $2, \frac{1}{6} \%$ & $69 \underline{27} \%$ & $10 \underline{39} \%$ \\
\hline
\end{tabular}

дилатації ЛП > 5,5 см та, особливо, $>$ 6,0 см порівняно з групою хворих з дилатацією $<5,5$ см, де переважають тільки легкі ТУ ( $<001)$. Таким чином, при більших розмірах ЛП виникає ризик тяжких ТУ, тому редукція/пластика ЛП показана таким пацієнтам у будь-якому випадку $[4,6,11]$.

Суттєвим елементом прояву ТЕ є наявність вушка ЛП, особливо в групі з фібриляцією передсердь. Так, відсутність його внаслідок ушивання (резекції, перев'язки) значно впливала на виникнення ТУ. В основній групі спостереження усунення вушка ЛП за відсутності тромбозу вушка та ЛП було виконано 5 пацієнтам. За наявності тромбозу ЛП під час операції вушко ЛП було ліквідовано в 56 пацієнтів. Але важливо визначити, який вплив справляє наявність вушка ЛП у віддалений термін у пацієнтів без попереднього тромбозу ЛП, який сам по собі може спричиняти тромбоемболії. Для аналізу було включено 77 пацієнтів з ФП, яким було виконано лігування вушка ЛП, але за відсутності тромбозу його вушка або самого ЛП. Тромбоемболічні ускладнення відзначали у $7(9,1 \%)(n=7 / 77)$ пацієнтів, у той час як за наявності фібриляції передсердь тромбоемболічні ускладнення мали місце у 71 $(18,7 \%)(n=78 / 380)$ пацієнта $(p<0,01)$.

Ці співвідношення структури ТЕ в цих категоріях представлені в таблиці 4.

Таблиця 4 демонструє, що наявність вушка ЛП при фібриляції передсердь суттєво збільшує як кількість TE, так і якість прояву тромбоемболічних ускладнень, за яких відзначається питома вага летальних і тяжких ускладнень порівняно з групою хворих з усуненим вушком ЛП, серед яких переважають тільки легкі ТУ $(\mathrm{p}<0,05)$. Таким чином, видалення вушка ЛП навіть

\section{Таблиця 4}

Структура ТУ при ПМК залежно від наявності вушка ЛП (без тромбозу вушка) у групі з фібриляцією передсердь

\begin{tabular}{|c|c|c|c|c|}
\hline \multirow{2}{*}{$\begin{array}{l}\text { Наявність } \\
\text { вушка після } \\
\text { операції }\end{array}$} & \multicolumn{4}{|c|}{$\begin{array}{c}\text { Ступінь прояву тромбоемболічних } \\
\text { ускладнень }\end{array}$} \\
\hline & $\begin{array}{l}\text { Тяжкі } \\
(\mathrm{n}=22)\end{array}$ & $\begin{array}{c}\text { Лerкi } \\
(\mathrm{n}=20)\end{array}$ & $\begin{array}{l}\text { Летальні } \\
\text { (n= 43) }\end{array}$ & Усього \\
\hline Присутнє & 28,20 & $11, \frac{8}{2} \%$ & $\frac{43}{60,6} \%$ & $100,0 \%$ \\
\hline Відсутнє & $14, \frac{1}{3} \%$ & $85, \frac{6}{7} \%$ & $0, \underline{0} \%$ & $\stackrel{7}{100,0} \%$ \\
\hline
\end{tabular}

у групі з постійною формою за відсутності інтраопераційного тромбування вушка ЛП не дає летальні ТЕ у віддалений термін, що свідчить про необхідність рутинного виконання цієї процедури в пацієнтів з фібриляцією передсердь $[1,5,9]$.

Ці дані свідчать про значущість феномену підвищеного тромбоутворення та необхідність у цій групі збільшити дозу антикоагулянтної терапії за допомогою антиагрегантної групи (клопідогрель 75 мг) [7, 12].

Суттєвим елементом впливу на тромбоемболічні ускладнення є фактор імплантованого протеза. Кількість ТЕ серед імплантованих штучних протезів наведено в таблиці 5. Серед двостулкових протезів найгірші показники визначені у моделі Edwards-Mira - 20,8 \%, а найкращий показник - у моделі On-x.

За структурою тромбоемболічних ускладнень немає статистично доведеного кращого показника серед моделей протезів (таблиця 6). Менше тяжких ТУ відзначено лише в моделі On-x - 15,4\%. Однак загалом двостулкові моделі показали хороші функціональні властивості. Винятком є одна модель, де найгірші показники в структурі (тяжкі та летальні) у моделі Edwards-Mira, яку знято з виробництва у 2008 році.

Значно знижена скоротливість ЛШ суттєво впливала на рівень ТУ (таблиця 7).

Згідно з даними таблиці 7, відзначається зворотна

\section{Таблиця 5}

Розподіл ТУ серед імплантованих мітральних протезів

\begin{tabular}{lcccc} 
& \multicolumn{2}{c}{$(\mathbf{n}=\mathbf{6 3 4 )}$} & \multicolumn{2}{c}{ Кількість ТУ } \\
\cline { 2 - 5 } Модель протеза & $\mathbf{n}$ & $\mathbf{\%}$ & $\mathbf{n}$ & $\mathbf{\%}$ \\
\hline Saint Jude Medical & 212 & 33,4 & 24 & 11,3 \\
\hline Carbomedics & 91 & 14,4 & 11 & 12,1 \\
\hline On-x & 139 & 21,9 & 13 & 9,3 \\
\hline Medtronic/ATS & 59 & 9,4 & 7 & 11,9 \\
\hline Edwards-Mira & 81 & 12,8 & 18 & 22,2 \\
\hline Моностулкові & 48 & 7,6 & 10 & 20,8 \\
\hline Біопротези & 4 & 0,6 & 0 & 0,0 \\
\hline Усього & $\mathbf{6 3 4}$ & $\mathbf{1 0 0 , 0}$ & $\mathbf{8 3}$ & $\mathbf{1 3 , 1}$
\end{tabular}




\section{Таблиця 6}

Структура ТУ при ПМК залежно від типу протеза $(n=634)$

\begin{tabular}{|c|c|c|c|c|}
\hline \multirow[b]{2}{*}{ Модель протеза } & \multicolumn{4}{|c|}{ Ступінь прояву ТУ } \\
\hline & $\begin{array}{c}\text { Тяжкі } \\
(n=22)\end{array}$ & $\begin{array}{c}\text { Легкi } \\
(n=17)\end{array}$ & $\begin{array}{c}\text { Летальні } \\
(n=44)\end{array}$ & $\begin{array}{c}\text { Усьoro } \\
(n=83)\end{array}$ \\
\hline $\begin{array}{l}\text { Saint Jude } \\
\text { Medical }\end{array}$ & 25,0 \% & 25,0 \% & $\stackrel{12}{50,0} \%$ & $100,0 \%$ \\
\hline Carbomedics & 18,2 \% & $27,3 \%$ & $54, \frac{6}{5} \%$ & $\frac{11}{100,0} \%$ \\
\hline On-x & $\underset{15,4}{2} \%$ & $38,5 \%$ & $46, \frac{6}{3} \%$ & $100,0 \%$ \\
\hline Medtronic/ATS & $28,6 \%$ & 28,6 \% & 42,8 \% & $\frac{\underline{7}}{100,0} \%$ \\
\hline Edwards-Mira & $38,9 \%$ & $0, \underline{0} \%$ & $\frac{11}{61,1} \%$ & $100,0 \%$ \\
\hline Моностулкові & 40,0 \% & $0, \underline{0} \%$ & 60,0 & $100,0 \%$ \\
\hline Біопротези & 0,0 & $0, \underline{0} \%$ & 0,0 & 0,0 \\
\hline 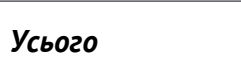 & $\underline{26,5} \%$ & $\stackrel{17}{20,5} \%$ & $5 \frac{44}{3,0} \%$ & $10 \underline{83}, 0 \%$ \\
\hline
\end{tabular}

пропорція між зменшенням фракції викиду та рівнем i структурою TE $(\mathrm{p}<0,05)$. Найгірші результати у групі 3 фракцією викиду ЛШ $\leq 0,44$. В усіх пацієнтів зазначено невідому тривалість фібриляції передсердь, що суттєво впливає на результат. Загальна частота ТЕ становила: для групи $\geq 0,55-9,1 \%(\mathrm{n}=35 / 383)$, для групи $0,45-0,54-17,5 \%(\mathrm{n}=33 / 189)(\mathrm{p}<0,01)$, для групи $\leq 0,44-24,2 \%(\mathrm{n}=15 / 62)(\mathrm{p}<0,01)$. Тому пацієнтів з мітральною вадою серця рекомендовано оперувати в II-III ФК зі збереженою систолічною функцією ЛШ, а в групі пацієнтів 3 наявністю фібриляції передсердь слід контролювати фактори згортання крові та знижувати густину крові шляхом додавання антиагрегантів (наприклад, клопідогрелю 75 мг на добу).

3 метою зменшення ризику тромбоемболічних епізодів у частини пацієнтів $(\mathrm{n}=54)$ (наявність тромбозу ЛП під час операції, включаючи вушко $(\mathrm{n}=27)$ та помірні ураження вінцевих артерій до операції (до 50 \%), атеросклероз аорти $(\mathrm{n}=27))$ до щоденної терапії антикоагулянтами був також долучений клопідогрель у дозі 75 мг на добу (таблиця 8). Схильність до підвищеного тромбоутворення в групі з тромбозом ЛП давала підстави для призначення антиагреганта $[7,11,12]$. У групі з помірною формою IXC, атеросклерозом аорти також існував ризик цього ускладнення через наявність холестеринових утворень не тільки у вінцевих артеріях, а також їх системне поширення в аорті, певні зміни в ендокарді лівих відділів серця, шо порушувало ламінарний кровотік та сприяло тромбоутворенню $[6,9,10]$. Значно знижена в'язкість крові суттєво впливала на рівень ТУ (див. таблицю 8). Тромбоембо-
Таблиця 7

Структура ТУ залежно від фракції викиду ЛШ $(n=83)$

\begin{tabular}{|c|c|c|c|c|}
\hline \multirow{2}{*}{$\begin{array}{l}\text { Фракція } \\
\text { викиду }\end{array}$} & \multicolumn{4}{|c|}{ Структура тромбоемболічних ускладнень } \\
\hline & Тяжкі & Легкі & Летальні & Усього \\
\hline $\begin{array}{l}\geqslant 0,55 \\
(n=383)\end{array}$ & $14, \frac{5}{3} \%$ & $\stackrel{14}{40,0} \%$ & $\stackrel{16}{45,7} \%$ & $100,0 \%$ \\
\hline $\begin{array}{l}0,45-0,54 \\
(n=189)\end{array}$ & $39,4 \%$ & $9, \frac{3}{1} \%$ & $\underline{51,5} \%$ & $100,0 \%$ \\
\hline $\begin{array}{l}\leqslant 0,44 \\
(n=62)\end{array}$ & $26,7 \%$ & $0, \underline{0} \%$ & $\frac{11}{73,3} \%$ & $100,0 \%$ \\
\hline $\begin{array}{l}Y_{c b 020} \\
(n=634)\end{array}$ & $\underline{26} \underset{26}{22} \%$ & $\underline{17}$ & $\stackrel{44}{53,0} \%$ & $100,0 \%$ \\
\hline
\end{tabular}

\section{Таблиця 8}

Структура ТУ залежно від використання антиагрегантів ( $n=83)$

\section{Структура ТУ}

\begin{tabular}{|c|c|c|c|c|}
\hline Показник & Тяжкі & Легкі & Летальні & Усього \\
\hline $\begin{array}{l}\text { Тромбоз ЛП (додат- } \\
\text { ково клопідогрель) } \\
(\mathrm{n}=27)\end{array}$ & $0, \underline{0} \%$ & $100,0 \%$ & $0, \underline{0} \%$ & $\frac{1}{100,0} \%$ \\
\hline $\begin{array}{l}\text { Тромбоз лП } \\
(\mathrm{n}=39)\end{array}$ & $28,6 \%$ & $57, \frac{4}{1} \%$ & $14, \frac{1}{3} \%$ & $\frac{7}{100,0} \%$ \\
\hline
\end{tabular}

Помірна IXC, атеро-

склероз (додатково клопідогрель) $\quad 0,0 \% \quad 50,0 \% \quad 50,0 \% \quad 100,0 \%$ $(\mathrm{n}=27)$

\begin{tabular}{|c|c|c|c|c|}
\hline $\begin{array}{l}\text { Помірна IXC, атеро- } \\
\text { склероз }(\mathrm{n}=31)\end{array}$ & $33,3 \%$ & $16, \frac{1}{7} \%$ & 50,0 \% & $100,0 \%$ \\
\hline $\begin{array}{l}\text { АКШ (додатко- } \\
\text { во клопідогрель, } \\
\text { аспірин) }(\mathrm{n}=101)\end{array}$ & $0, \underline{0} \%$ & 100,0 \% $\%$ & 0,0 & $100,0 \%$ \\
\hline
\end{tabular}

лічні ускладнення у групі з тромбозом ЛП та призначенням клопідогрелю відзначали в $1(3,7 \%)(\mathrm{n}=1 / 27)$ пацієнта, а в аналогічній групі з тромбозом ЛП, але без призначення клопідогрелю, додатково до непрямих антикоагулянтів ТУ - у $7(17,9 \%)(\mathrm{n}=7 / 39)$ пацієнтів $(\mathrm{p}<0,05)$. Якщо в першій групі ТУ була легкою $(\mathrm{n}=1)$, то в другій групі було $(\mathrm{n}=1)$ померлих, тяжких $(\mathrm{n}=2)$, легких $(\mathrm{n}=4)$.

Висновки. Тромбоемболічні ускладнення - одні з найчастіших і тяжких проявів після ПМК. Найкраші результати віддаленого періоду після ПМК спостерігались у пацієнтів, які були прооперовані у II-III ФК за NYHA та за наявності синусового ритму. Особливу увагу у віддаленому періоді слід звернути на пацієнтів, які перебувають у групі ризику з наявністю фібриляції передсердь, що призводить до виникнення ТУ. Операцію «Лабіринт-3», пластику ЛП потрібно виконувати для відновлення синусового ритму, а також для зменшення прогресування серцевої недостатності та ТУ. За 
наявності фібриляції передсердь слід виконувати усунення вушка ЛП. Після ПМК пацієнти з фібриляцією передсердь повинні перебувати під постійним диспансерним наглядом кардіолога за місцем проживання та з призначенням адекватної антикоагулянтної терапії.

\section{Список використаних джерел References}

1. Лазоришинец ВВ, Кнышов ГВ, Попов ВВ. Лечение митральных пороков сердца, осложненных фибрилляцией предсердий. Киев;2014. С. 101.

Lazoryshynets VV, Knyshov GV, Popov VV. [Treatment of mitral valve disease complicated by atrial fibrillation]. Kyiv; 2014. p.101. Russian.

2. Орлов ВИ, Мурзабекова ЛИ. Кардиохирургическое лечение пациентов с приобретенными пороками сердца: отдаленные результаты и клинические факторы, влияющие на них. Российский кардиологический журнал. 2005;55(5):87-94.

Orlov VI, Murzabekova LI. [Cardiac surgery for patients with acquired heart valvular disease: long-term results and clinical factors influencing them]. Russian Journal of Cardiology. 2005;55(5):87-94. Russian.

3. Орловский ПИ, Гриценко ВВ, Вавилова ТВ, Кадинская МИ, Петришина ТИ, Мочалов ОЮ и др. Два подхода к коррекции нарушений гемостаза у больных с механическими искусственными клапанами сердца в отдаленные сроки наблюдения. Вестник хирургии им. И. И. Грекова. 2004;163(5):20-4.

Orlovskiĭ PI, Gritsenko VV, Vavilova TV, Kadinskaia MI, Petrishina TI, Mochalov OIu, et al. [Two approaches to correction of disturbed hemostasis in patients with mechanical artificial heart valves at the long-term follow-up]. Vestn Khir Im I I Grek. 2004;163(5):20-4. Russian.

4. American College of Cardiology; American Heart Association Task Force on Practice Guidelines (Writing Committee to revise the 1998 guidelines for the management of patients with valvular heart disease); Society of Cardiovascular Anesthesiologists, Bonow RO, Carabello BA, Chatterjee K, de Leon AC Jr, Faxon DP, Freed MD, Gaasch WH, Lytle BW, et al. ACC/AHA 2006 Guidelines for the Management of Patients With Valvular Heart Disease. J Am Coll Cardiol. 2006;48(3):e1-148. https://doi.org/10.1016/j.jacc.2006.05.021
5. Avitall B, Kalinski A. Cryotherapy of cardiac arrhythmia: from basic science to the bedside. Heart Rhythm. 2015;12:2195-203. https://doi.org/10.1016/j. hrthm.2015.05.034

6. Butchart EG, Payne N, Li HH, Buchan K, Mandana K, Grunkemeier GL. Better anticoagulation control improves survival after valve replacement. J Thorac Cardiovasc Surg. 2002;123:715-23.

7. Damiano RJ Jr, Badhwar V, Acker MA, Veeragandham RS, Kress DC, Robertson JO, Sundt TM. The CURE-AF trial: a prospective, multicenter trial of irrigated radiofrequency ablation for the treatment of persistent atrial fibrillation during concomitant cardiac surgery. Heart Rhythm. 2014;11:39-45. https://doi.org/10.1016/j. hrthm.2013.10.004

8. January CT, Wann LS, Alpert JS, Calkins H, Cigarroa JE, Cleveland JC Jr, et al. 2014 AHA/ACC/HRS guideline for the management of the patients with atrial fibrillation: a report of the American College of Cardiology/American Heart Association Task Force on Practice Guidelines and the Heart Rhythm Society. J Am Coll Cardiol. 2014;64:e176. https://doi.org/10.1016/j.jacc.2014.03.022

9. La Meir M. Surgical options for treatment of atrial fibrillation. Ann Cardiothorac Surg. 2014;3:30-7. https://doi. org/10.3978/j.issn.2225-319X.2014.01.07

10. Masoudi FA, Calkins H, Kavinsky CJ, Slotwiner DJ, Turi ZG, Drozda JP Jr, et al. 2015 ACC/HRS/SCAI left atrial appendage occlusion device societal overview: a professional societal overview from the American College of Cardiology, Heart Rhythm Society, and Society for Cardiovascular Angiography and Interventions. Catheter Cardiovasc Interv. 2015;86:791-807. https://doi.org/10.1002/ ccd. 26170

11. Prabhu S, McLellan AJ, Walters TE, Sharma M, Voskoboinik A, Kistler PM. Atrial structure and function and its implications for current and emerging treatments for atrial fibrillation. Prog Cardiovasc Dis. 2015;58:152-67. https:// doi.org/10.1016/j.pcad.2015.08.004

12. Stefanidis C, Nana AM, De Canniure D, Antoine M, Jansens JL, Huynh CH, Le Clerc JL. 10-Year Experience With the ATS Mechanical Valve in the Mitral Position. Ann Thorac Surg. 2005;79:1934-8. https://doi.org/10.1016/j.athoracsur.2005.01.002

\title{
Remote Thromboembolic Complications after Mitral Valve Replacement
}

\author{
Pukas K. V. \\ National Amosov Institute of Cardiovascular Surgery, Kyiv, Ukraine
}

\begin{abstract}
The aim of this research was to investigate remote thromboembolic complications after mitral valve replacement. Analysis group included 634 patients with isolated mitral valve disease who were on treatment at the National M.M. Amosov Institute of Cardiovascular Surgery from 1 January, 2005, till 1 January, 2007. The mean duration of the follow-up was $9.3 \pm 0.9$ years. The main parameters studied within 10 years were survival $(69.4 \%)$, stability of good and satisfactory results (57.3\%), freedom from thromboembolic complications $(79.7 \%)$, freedom from reoperations $(95.4 \%)$. The study included $299(47.1 \%)$ men and $335(52.9 \%)$ women. The mean age of the subjects was $53.1 \pm 8.5$ years. $89(34.1 \%)$ patients were classified in class II by NYHA, $199(31.7 \%)$ in class III and $380(60.0 \%)$ in class IV. The most common etiology of the dis-
\end{abstract}


order was rheumatism combined with lipoidosis and myxomatosis $(67.5 \%)$. The mean duration of rheumatic disease was $17.3 \pm 4.9$ years. The mean duration of atrial fibrillation was $3.1 \pm 0.9$ years.

Mitral valve replacement (MVR) was carried out in all the subjects. The following types of bileaflet valve prostheses were used for mitral valve replacement: St. Jude, On-X, Carbomedics, Edwards MIRA. Based on the analysis, the risk factors of remote thromboembolic complications were revealed (type of the prosthesis, adequacy of anticoagulant therapy, occurrence of prosthetic-dependent complications such as prosthetic endocarditis, panus or thrombosis of mitral valve prosthesis, increased left atrium size of more than $5.0 \mathrm{~cm}$, contractility disorders). Mitral valve replacement is recommended for the patients of II-III class with sinus rhythm.

After the mitral valve replacement, patients (especially those at risk: patients with long-term atrial fibrillation, rheumatic heart disease, atriomegaly) need permanent clinical supervision by cardiologist at the place of residence. In order to prevent and reduce the risk of thromboembolic complications, concomitant procedures are obligatory during mitral valve replacement: ligation of left atrium appendage, Cox Maze procedure, left atrium plasty and anticoagulant therapy escalation using an antiplatelet agent.

Keywords: mitral valve disease, remote period, thromboembolic complication, left atrium plasty, mitral valve replacement.

Стаття надійшла в редакцію 22.07.2019 р. 